\title{
ПЛАНОВОЕ УПРАВЛЕНИЕ ЭКОНОМИКОЙ: ИСТОРИЧЕСКИЙ АСПЕКТ
}

\author{
Орешин В.П.
}

Обоснована необходимость системы плановых документов: прогноз, план (индикативный и директивныий), программы, бюджет. Рассмотрень проблемы мотивачии представителей бизнеса следовать установкам индикативного плана. Обоснована необходимость единого органа - Госплана, отвечающего за ход экономического развития.

DOI: $10.20537 /$ mce2020econ02

Планирование динамики любого циклически воспроизводящегося объекта - непременное условие его успешного развития. Это касается как бизнес структур, так и национальной экономики в целом.

Надо четко различать два близкие по звучанию, но разные по содержанию понятия: «планирование развития экономики» и «плановое ведение хозяйства». Если первое сводится к разработке научно обоснованных плановых показателей и не всегда предполагает контроль за их исполнением, то второй подход «плановое ведение хозяйства» в качестве обязательной составляющей предполагает жесткий контроль за ходом достижения намеченных целевых индикаторов и поощрительные или репрессивные меры за их реализацию/невыполнение.

Наша страна, волею судеб, стала пионером в области, как планирования экономического развития, так и в области планового ведения хозяйства. Именно в нашей стране были составлены первые планы и программы развития национальной экономики, создан специальный орган (Госплан СССР), разрабатывались прогнозы и стратегические планы развития национальной экономики. Надо отметить, что в основе системы планирования в СССР лежал план ГОЭЛРО - план коренного преобразования экономической системы Царской России на пути развития демократических отношений (советская власть) и коренного технического перевооружения всей экономики (электрификация всей страны).

Распространенное высказывание Ленина «Коммунизм есть советская власть плюс электрификация всей страны» резюмирует работу над 
поиском действенных форм управления экономикой в первые годы Советской власти.

Целое столетие, начиная с плана ГОЭЛРО, наши ученые и государственные деятели разрабатывали и совершенствовали инструментарий планового управления экономикой. Была разработана система планового ведения хозяйства, которая доказала свою силу и дееспособность [1-3].

Бездумное следование рекомендациям Вашингтонского консенсуса в 90-х годах прошлого века, по существу, перечеркнуло это движение мировой системы к плановому ведению мирового хозяйства.

Преследуя цель ускоренного экономического развития, нашему руководству необходим целостный документ, определяющий перспективы развития экономики и социальной сферы на 15-20 лет, типа плана ГОЭЛРО, который в свое время был взят за основу В.И. Лениным и его соратником Г.М. Кржижановским. Однако, мало составить научно обоснованный план, надо довести его до каждого человека, превратить его в инструмент проведения экономической политики.

Знакомство с перепиской Ленина со своими коллегами по поводу планирования экономики и конкретно по поводу плана ГОЭЛРО свидетельствуют о том, что этому вопросу придавалось особое значение. Проблемы стратегического планирования были в центре внимания руководства страны при проведении экономической политики [4, с.370, 375, 397, 399, 400, 422-423, 431].

Опыт развитых стран мира свидетельствует о целесообразности применения этого инструментария не только в условиях преобладания государственного хозяйства (как это было в Советском Союзе), но и в современной многоукладной экономике. Идеи планирования национальной экономики активно применялись для решения проблем эффективного управления экономическим развитием во многих странах мира. Наибольшее развитие они получили в Японии, Франции, Скандинавских странах.

Для эффективного управления ходом экономического развития со стороны государства нужен не просто один устанавливающий будущее документ (прогноз, программа, план), нужна система плановых документов, устанавливающих в той или иной форме развитие экономической системы и ее частей. Эта система включает: 
долгосрочный прогноз и/или стратегию развития, например, в виде Комплексной программы научно-технического прогресса и Генеральной схемы развития и размещения производительных сил страны";

среднесрочный индикативный план как совокупность государственных программ развития отдельных структурно-отраслевых, структурно-территориальных элементов экономики;

годовой индикативно-директивный план развития конкретных корпораций и фирм различных форм собственности: государственных, муниципальных, корпоративных, частных, смешанных;

государственный бюджет.

Закон о стратегическом планировании №172-Ф3, принятый 23 июня 2015 г. [5], в рамочной форме регламентирует процедуру обоснования перспектив развития национальной экономики. Он призван определить общее направление движения экономики страны. Его разработка и принятие не позволяет экономике выйти за пределы возможных ограничений как экономического, социального, а также экологического плана.

Вместе с тем, надо сказать, что стратегическое планирование является лишь одним из элементов планирования национальной экономики, наряду с другими необходимыми элементами.

Этот закон полезен также потому, что он знаменует переход к более активному (по сравнению с экономическим прогнозом) проведению руководством страны экономической политики. Следует отметить своевременность приятия закона о планировании будущего развития экономики страны, поскольку базировать принятие макроэкономических решений, опираясь на экономический прогноз (даже комплексный, как это предполагается в Законе 115-ФЗ - это односторонняя и потому не совсем правильная постановка задачи эффективного управления социально-экономическим развитием.

\footnotetext{
* Процедура разработки этих документов была достаточно подробно разработана в советское время. Так, разработка Комплексной программы научно - технического прогресса и его социально-экономических последствий велась под руководством академиков В.А. Котельникова и А.И. Анчишкина с привлечением обширной когорты ученых из научно-исследовательских институтов АН СССР, Госплана СССР, университетов страны. Разработка Генеральной схемы развития и размещения производительных сил страны велась Советом по развитию производительных сил СССР с привлечением родственных организаций в союзных республиках.
} 
Этот подход предполагает опору лишь на предвидение экономических явлений в будущем, но не предусматривает установку средств воздействия государства на ход экономического развития и оценку последствий принятых государственных решений, и учет последствий этих действий. Правы ученые, отстаивающие идею необходимости индикативного плана как базу принятия решений по ключевым вопросам экономического развития [6].

На наш взгляд, в качестве исходного пункта и основы разработки государственного бюджета, как инструментария активного воздействия государства на ход экономического развития, необходимо использовать не экономический прогноз, а индикативный план, который предполагает четкую постановку средств государственного управления ходом развития экономической системы.

Методологические вопросы государственного управления экономическим развитием обобщены в некоторых работах современного периода $[7,8]$.

Государственное прогнозирование социально-экономического развития - это система научно обоснованных представлений о направлениях социально-экономического развития экономики страны, основанных на принципах рыночного хозяйствования [9].

Высшим достижением методологии прогнозирования является сценарный или ситуационный прогноз. При разработке ситуационного прогноза целесообразно выделять внешние и внутренние условия формирования темпов и пропорций на будущее. При этом, среди основных внешних условий учитываются: динамика развития мировой экономики, прогнозируемые изменения мировых цен на нефть, уровень спроса на нефть и газ со стороны основных стран-потребителей, размеры выплат по внешнему долгу, степень участия России в международном разделении труда.

Внутренние условия можно подразделить на две группы. Вопервых, объективные условия, влияние на которые со стороны правительства в среднесрочной перспективе существенно ограничено. Это, прежде всего, демографическая ситуация и ее развитие; состояние производственного аппарата, степень его изношенности, доля резервных конкурентоспособных мощностей; высокая капиталоемкость и ресурсоемкость российского производства, и существенные сроки освоения новых месторождений энергетических и сырьевых ресурсов для потребностей растущей экономики. 
Во-вторых, условия, формируемые под влиянием проводимой правительством страны экономической политики. К ним относятся такие параметры, как инфляция, тарифы на продукцию и услуги естественных монополий, ставки налогов и экспортных пошлин, импортные тарифы, индексация заработной платы в бюджетной сфере, государственные расходы инвестиционного характера.

Основное назначение сценарных условий состоит в комплексном и наглядном представлении экономической политики государства с формулировкой различимых по результатам вариантов социальноэкономического развития и оценкой положительных и негативных факторов, воздействующих на экономику.

Роль прогнозирования в РФ, на наш взгляд, чрезмерно завышена: «Можно сказать, что прогноз в России больше чем прогноз, так как он представляет собой оцифрованную экономическую политику, предвидение принимаемых экономических решений и их соответствия, или напротив, несоответствия сложившимся экономическим тенденциям» [10]. В прогнозе нет, и не может быть обоснованной экономической политики. Прогноз, как правило, многовариантен. Если руководством страны выбран один единственный вариант развития экономических событий, прогноз тут же трансформируется в план. Однако, до такой стадии государственного вмешательства в экономические события наши экономические деятели пока не доросли. Была попытка трансформировать пассивносозерцательную деятельность министерства экономического развития в более активную форму воздействия, предпринятая А.Р. Белоусовым [11] в бытность его министром экономического развития. Однако, она не была практически реализована. Предложения правительства по определению главных путей и средств решения злободневных проблем российской экономики остаются тайной за семью печатями.

Прогнозировать экономическую динамику в сценарных условиях мы научились, хотя надо отметить, что это в первую очередь, - peзультат научной деятельности наших предшественников: Кржижановского Г.М., Фельдмана Г., Струмилина С.Г., Кондратьева Н.Д., Бора М.3., Анчишкина А.И.

Прогноз сам по себе не является инструментом управления объектом. Сложной и до конца нерешенной задачей является трансформация совокупности прогнозных данных в управляющие параметры экономического развития, в показатели целевых программ, которые рассматриваются в качестве главных инструментов проведения государственной эконо- 
мической политики. При этом государственные заказчики федеральных целевых программ представляют в Минэкономразвития России и Минфин России предложения по федеральным целевым программам, подлежащим финансированию за счет средств государственного бюджета.

Интересное предложение относительно места различных инструментов государственного управления экономическим развитием выдвинул А.Р. Белоусов на заседании коллегии Минэкономразвития 29 апреля 2013 г. Он пишет: «Правительство утвердило 40 государственных программ ... и уже в этом году программы должны стать элементом бюджетного планирования, быть интегрированы в бюджетный процесс» [12]. Это знаменательная постановка проблемы, которая может в корне изменить место и роль государства в управлении ходом экономического развития. Однако, имеются проблемы практического применения этой логики и процедуры реализации государственных решений.

Набор методов по обоснованию перспектив развития национальной экономики традиционен и включает: программно-целевой, балансовый, нормативный, метод оптимизации плановых решений, метод экономико-математического моделирования. Полезны здесь будут наработки наших специалистов, таких как Глазьев С.Ю. [13], Варшавский А.Е. [14], Клепач А.Н. [10], Ивантер В.В. [15], Белоусов Д.Р. [16].

Методы планирования экономики разработаны и апробированы в советское время [17]. Создать что-либо новое в этой области достаточно сложно. Инструменты и методы планирования отражены во множестве нормативных актов, монографий и учебников [1-3].

Определенную ценность представляет в этой сфере краткое изложение позиции японских специалистов относительно содержания и целей разработки двенадцатого плана развития Японии на 1992-1996 гг. [18]. Особой новизны относительно структуры плана и процедур разработки его показателей японцы не придумали. Они взяли с «снятом» виде методику планирования народного хозяйства в Советском Союзе и применили ее к специфическим особенностям Японии. В первую очередь специфика эта касалась учета рыночных условий экономического развития.

В процессе управления экономическим развитием с помощью индикативного плана стоит задача адаптации методов и подходов планирования к современному состоянию экономической системы, а именно к условиям преобладания в экономике страны объектов не государственной, а частной собственности. 
Для этого необходимо разработать процедуру мотивации представителей бизнеса следовать установкам индикативного плана. Эта процедура разработана и нашла применение во Франции, но требует адаптации к российским условиям.

\section{СПИСОК ЛИТЕРАТУРЫ}

1. Методические указания к разработке государственных планов экономического развития. М.: Экономика, 1983.

2. Планирование народного хозяйства / Учебник для экономических факультетов вузов под ред. Л.Я.Берри. М.: Экономика, 1973.

3. Планирование национальной экономики / под ред. А.И.Анчишкина. М.: Изд-во «Прогресс», 1981-82 гг.

4. Ленин В.И. Полное собрание сочинений. Издание четвертое, том 35. М.: ОГИЗ, Издательство политической литературы, 1950.

5. Федеральный закон от 28 июня 2014 г. №172-Ф3 «О стратегическом планировании в Российской Федерации».

6. Швырков Ю.М. Государственное индикативное планирование: теория, история, современная практика (российский и зарубежный опыт) // М.: Издво «Проспект», 2007.

7. Стратегическое управление $\backslash$ под ред. Орешина В.П. М.: МАТИ, 2010.

8. Планирование и прогнозирование $\backslash$ под ред. Кузьбожева Э.Н. 2006.

9. Закон Российской Федерации «О государственном прогнозировании и программах социально-экономического развития Российской Федерации» (№115-Ф3 от 20 июля 1995г.).

10. Клепач А.Н. Поворот к стратегическому планированию: тернии и перспективы // Вопросы политической экономии. 2016. №1. С. 44-63.

11. Белоусов А.P. Тезисы доклада на расширенном заседании Минэкономразвития «Об итогах деятельности Министерства экономического развития РФ в 2013 г. и на 2014 г.». 29 апреля 2013г.

12. Белоусов А.P. Тезисы выступления на заседании коллегии Минэкономразвития «Об итогах деятельности Министерства экономического развития РФ в 2013 г. и задачах на 2013 г.». 29 апреля 2013 г.

13. Глазьев С.Ю. О формировании системы стратегического управления развитием экономики / Планирование: перезагрузка. Под ред. Бузгалина А.В. М.: Культурная революция. 2016. 
14. Варшавский А.Е. Значительное снижение неравенства доходов - важнейшее условие перехода к инновационной экономике, основанной на знаниях // Экономика и математические методы. 2007. Т. 43. № 4. С. 35-55.

15. Прогнозирование перспектив технологической модернизации экономики России. Коллективная монография. Отв.ред. Ивантер В.В., Комков Н.И., М.: Макс-Пресс, 2010.

16. Долгосрочное прогнозирование социально-экономического и научнотехнологического развития России: методология. Коллективная монография. Белоусов Д.Р., Апокин А.Ю., Сухарева И.О., М.: Макс-Пресс 2012.

17. Методы государственного регулирования экономики. М.: Инфра-М, 2014.

18. Симада X. «Экономическое планирование Японии» (специальный выпуск), 1994 г.

\title{
PLANNED MANAGEMENT OF THE ECONOMY: HISTORICAL OVERVIEW
}

\author{
Oreshin V.P.
}

The relevancy of a project plan system including forecast, indicative plan and guiding documents, as well as budget plan, is motivated. Problems of entrepreneurship behavior motivation for following the indicative plan are discussed. The necessity for the integrated government agency as State Planning Committee holding responsibility for the country's economic development was also rationalized. 